\title{
A Middle-Late Eocene inflorescence of Caryophyllaceae from Tasmania, Australia ${ }^{1}$
}

\author{
GREgORY J. JORDAN² AND MichaEl K. MACPHAIL ${ }^{3}$
}

School of Plant Science, University of Tasmania, Private Bag 55, Hobart 7001, Tasmania, Australia

\begin{abstract}
A new genus and species (Caryophylloflora paleogenica genus and species nova G. J. Jord. \& Macphail) are proposed for a fossil inflorescence found in Middle-Late Eocene sediments at Locharbour, northeastern Tasmania, Australia. A parsimony analysis of 75 extant species of the order Caryophyllales and five outgroups placed the fossil within Caryophyllaceae, either subfamily Alsinoideae or Caryophylloideae. The analysis used molecular $(r b c \mathrm{~L}$ and/or $m a t \mathrm{~K})$, morphological, and anatomical data for the extant species and morphological data for the fossil. Tests on extant species imply that the placement of the fossil should be convincing. The fossil appears to be of a lineage distinct from any extant Australian Caryophyllaceae. In situ pollen are consistent with the form species, Periporopollenites polyoratus. This relatively simple pollen type first appears in Australia and New Zealand in the Late Cretaceous, the oldest known record of the Caryophyllaceae. The last appearance of P. polyoratus in Australia is in the Oligocene, and extant Australian members of the Caryophyllaceae are best interpreted as having evolved from species that dispersed from elsewhere during the Neogene or Quaternary.
\end{abstract}

Key words: Antarctica; Australia; Caryophyllaceae; Centrospermae; Eocene; fossil; Paleogene; phylogeny; pollen.

The Caryophyllaceae is a large, cosmopolitan family of 86 genera and about 2200 species of herbs and small shrubs (Bittrich, 1993). Only three of the genera are large shrubs or small trees, Sanctambrosia, endemic to San Ambrosio Island, Chile, and the Hawaiian endemics, Alsinidendron and Schiedea (Bittrich, 1993). The family is included in the order Caryophyllales, which Cronquist (1981) defined to contain about 600 genera and 10000 species. This is a monophyletic group (Cuenod et al., 2002). Cactaceae, Aizoaceae, Amaranthaceae, and Portulacaceae are other large families in the same order. Savolainen et al. (2000) defined Caryophyllales more broadly but this work will use Cronquist's (1981) narrow definition.

The fossil record of the family is sparse, with published prePleistocene records consisting almost exclusively of pollen. Most Caryophyllaceae have more or less spherical, periporate, spinulose, microechinate or microreticulate annular perforate or punctate pollen with simple apertures (Nowicke, 1994; Punt and Höen, 1995). Fossil pollen matching this description are included in Periporopollenites Pflug \& Thompson in Thompson \& Pflug 1953, Malvacipollis and Chenopodipollis Krutzsch 1966. Periporopollenites includes pollen previously assigned to Periporites Van der Hammen 1956, Caryophyllidites Couper 1960, Parsonsidites Couper 1960, Liquidambarpollenites Ratz 1937 ex Potonié 1960, Polyporina Naumova 1939 ex Potonié 1960, Caryophyllaceaepites Biswas 1962, and Chenopodipollis. Malvacipollis and Chenopodipollis are still in use, but now only encompasses pollen of Euphorbiaceae and Amaranthaceae (defined to include Chenopodiaceae), respectively (Truswell et al., 1985).

Periporopollenites polyoratus (Couper 1960) Stover and

\footnotetext{
${ }^{1}$ Manuscript received 1 August 2002; revision accepted 21 November 2002.

The authors thank Phillipe Cuenod for molecular data; Alan Partridge for pollen specimens and discussion, David Steele of the Central Science Laboratory, University of Tasmania, for help with electron microscopy, Jane Francis for advice on sedimentology at Locharbour, Laurie Adams, Judy West, Robert Hill, and Andrew Rozefelds.

${ }^{2}$ Author for reprint requests (e-mail: greg.jordan@utas.edu.au).

${ }^{3}$ Current address: Department of Archaeology and Natural History, Research School of Pacific and Asian Studies, Australian National University, Canberra 0200, A. C. T. Australia.
}

Partridge 1973 has the longest geological range of fossil pollen types assigned to Caryophyllaceae. Its earliest record is Late Campanian from the Gippsland and Otway Basins in southeast Australia (Stover and Partridge, 1973) and South Island, New Zealand (Raine, 1984). Its last recorded appearance is Oligocene. Younger records of Periporopollenites that may be derived from members of Caryophyllaceae are morphologically distinct species. They include Oligocene specimens of P. pallidus and P. vesicus (Nott and Owen, 1992), Early Miocene specimens of $P$. vesicus and two undescribed Periporopollenites species (Owen, 1988), and an undescribed Early-?Middle Miocene grain (Tulip et al., 1982).

Caryophyllaceae-type pollen first appears in Europe in the Miocene (Muller, 1981). This late appearance is surprising considering the much higher diversity of the family in the Northern Hemisphere (Bittrich, 1993) and the earlier Southern Hemisphere records. Eocene seeds from England, Hantsia pulchra and H. glabra (Chandler, 1961, 1963), have been attributed to the family. These are the only macrofossil records of the family, but their taxonomic status is uncertain (Chandler, 1961).

Morphological convergence means that the pollen records of Caryophyllaceae need to be interpreted carefully. All the features of typical Caryophyllaceae pollen occur in other families of the order, notably Amaranthaceae, Rivinaceae, and Nyctaginaceae. Periporate pollen also occurs in unrelated families such as Papaveraceae, Convolvulaceae, Euphorbiaceae, and Hamamelidaceae.

This work describes a fossil inflorescence from Middle-Late Eocene sediments at Locharbour, northwestern Tasmania, Australia, and the relationships of the in situ pollen with dispersed fossil pollen types. Recent progress in understanding angiosperm evolution has been made by determining the relationships of extinct species to living taxa without forcing fossils into extant genera or families (Dilcher, 2000). This work therefore uses a phylogenetic analysis to determine the relationships of the fossil to extant groups. Formal phylogenetic analysis was necessary because of extensive morphological homoplasy within the order. 
TABLE 1. Morphological, anatomical, and biochemical characters and states. All multistate characters were treated as unordered.

\begin{tabular}{|c|c|}
\hline Character & States \\
\hline 1. Inflorescence & $\begin{array}{l}0=\text { not dichasial } \\
1=\text { dichasial }\end{array}$ \\
\hline 2. Paired floral bracts & $\begin{array}{l}0=\text { absent } \\
1=\text { present }\end{array}$ \\
\hline 3. Flowers & $\begin{array}{l}0=\text { bisexual } \\
1=\text { unisexual }\end{array}$ \\
\hline 4. Perianth & $\begin{array}{l}0=\text { with both petals and sepals } \\
1=\text { with sepals only }\end{array}$ \\
\hline 5. Calyx merosity & $\begin{array}{l}0=\text { pentamerous } \\
1=\text { pleiomerous } \\
2=\text { trimerous } \\
3=\text { tetramerous }\end{array}$ \\
\hline 6. Calyx parts & $\begin{array}{l}0=\text { free } \\
1=\text { fused }\end{array}$ \\
\hline 7. Stamen position & $\begin{array}{l}0=\text { unassociated with calyx } \\
1=\text { episepalous/pseudo-obdiplos- } \\
\text { temonous } \\
2=\text { alternisepalous }\end{array}$ \\
\hline 8. Androecium & $\begin{array}{l}0=\text { numerous parts } \\
1=\text { same number of elements as } \\
\text { calyx } \\
2=\text { twice as many elements as ca- } \\
\text { lyx }\end{array}$ \\
\hline 9. Filaments & $\begin{array}{l}0=\text { filiform } \\
1=\text { subulate/tapering }\end{array}$ \\
\hline 10. Stamens & $\begin{array}{l}0=\text { all free } \\
1=\text { fused into bundles }\end{array}$ \\
\hline 11. Stamen number & $\begin{array}{l}0=\text { multiple of calyx elements } \\
1=\text { number reduced } \\
2=\text { indeterminate }\end{array}$ \\
\hline 12. Anther attachment & $\begin{array}{l}0=\text { dorsifixed } \\
1=\text { basifixed }\end{array}$ \\
\hline 13. Fusion of floral whorls & $\begin{array}{l}0=\text { free } \\
1=\text { anthers fused to free perianth } \\
\text { parts } \\
2=\text { perigynous } \\
3=\text { epigynous }\end{array}$ \\
\hline 14. Pollen aperture type & $\begin{array}{l}0=\text { furrows }(\text { colpi }) \\
1=\text { pores }\end{array}$ \\
\hline 15. Pollen aperture number & $\begin{array}{l}0=\text { three } \\
1=4-7 \\
2=\text { more than seven }\end{array}$ \\
\hline 16. Pollen & $\begin{array}{l}0=\text { not spinulose or echinate } \\
1=\text { spinulose or echinate }\end{array}$ \\
\hline 17. Pollen & $\begin{array}{l}0=\text { punctate or perforate } \\
1=\text { not punctate or perforate }\end{array}$ \\
\hline 18. Carpel number & $\begin{array}{l}0=\text { indefinitely large } \\
1=\text { four or five } \\
2=\text { two or three } \\
3=\text { one }\end{array}$ \\
\hline 19. Styles & $\begin{array}{l}0=\text { free } \\
1=\text { fused } \\
2=\text { one carpel }\end{array}$ \\
\hline 20. Leaves & $\begin{array}{l}0=\text { alternate } \\
1=\text { opposite }, \text { not connate around } \\
\text { stem } \\
2=\text { opposite, connate around stem }\end{array}$ \\
\hline 21. Pigments & $\begin{array}{l}0=\text { anthocyanin type } \\
1=\text { betalaine type }\end{array}$ \\
\hline
\end{tabular}

TABle 1. Continued.

\begin{tabular}{ll}
\hline \hline \multicolumn{1}{c}{ Character } & \multicolumn{1}{c}{ States } \\
\hline 22. Sieve element plastid & $0=$ without protein filaments \\
& $1=$ peripheral ring of protein fila- \\
& ments present \\
23. Sieve element plastid crystals $\quad 0=$ absent & $1=$ globular \\
& $2=$ polygonal/angular/cuboidal \\
\hline
\end{tabular}

\section{MATERIALS AND METHODS}

Fossil site and paleoenvironmental context-The fossil came from a lens of laminated siltstone in gravel exposed in the Locharbour tin mine in northeastern Tasmania $\left(40^{\circ} 56^{\prime} 16^{\prime \prime} \mathrm{S}, 148^{\circ} 0^{\prime} 34^{\prime \prime} \mathrm{E}, 60 \mathrm{~m}\right.$ a.s.1.). The siltstone is consistent with a cut-off channel in a braided stream deposit. The sediments are part of extensive mid-Cretaceous-early Neogene freshwater deposits in the region (Baillie, 1989). The associated palynoflora falls in the Lower Nothofagidites asperus zone of Stover and Partridge (1973), implying a Middle or possibly Late Eocene age.

The living relatives of fossil species at Locharbour and coeval sites suggest that floristically the vegetation at the time of deposition was diverse, cool climate rainforest dominated by genera with extant species in temperate and tropic-montane rainforests (Carpenter et al., 1994; Macphail et al., 1994). The Locharbour fossil flora includes the conifers Phyllocladus aberensis (Hill, 1989), Willungia oppositifolia (Hill and Pole, 1992), Acmopyle tasmanica, Dacrycarpus mucronatus (Hill and Carpenter, 1991), and Araucaria (Carpenter et al., 1994), and the angiosperms Eucryphia aberensis (Barnes and Jordan, 2000) and Banksieaephyllum attenuatum (Hill and Christophel, 1988).

Specimen preparation-One partial inflorescence was found by manually splitting a block of sediment. Brushing the block with a fine brush under running water exposed this fossil progressively. Some individual anthers were squashed on glass slides and mounted in phenol glycerine jelly for light microscopy. Others were soaked in 50\% hydrofluoric acid for approximately 1 $\mathrm{h}$ to remove residual sediments, then placed on double-sided conductive tape on aluminum stubs. These were sputter coated with gold to approximately 40 $\mathrm{nm}$ thick and observed under high vacuum with an ESEM 2020 Environmental Scanning Electron Microscope (ElectroScan, Wilmington, Massachusetts, USA).

Data for cladistic analyses - This work seeks the most parsimonious phylogeny of extant species and the fossil (e.g., Jordan and Hill, 2000). Molecular and morphological data were used for extant species and only morphological data for the fossil. Eighty extant genera with published $r b c L$ or matK nucleotide sequences were used (Appendix 1, archived at the Botanical Society of America website [http://ajbsupp.botany.org/V90/]). They were 75 genera of Caryophyllales and genera from five families chosen as outgroups based on Savolainen et al. (2000) and Cuenod et al. (2002). All recognized families of the order were represented.

In total $41 \mathrm{rbcL}$ and $69 \mathrm{mat} K$ sequences were used, with both $r b c L$ and $m a t K$ sequences for 30 genera. For 76 genera only one species was used. In 14 genera the $r b c L$ and $m a t K$ sequences were from different species, and the sequences were combined to minimize the sparsity of the data matrices. This approach could cause misinterpretation if the relevant pairs of species were not monophyletic with regard to the other species analyzed. However, the sparse sampling of taxa makes this unlikely. Scoring of morphological characters allowed for polymorphism in these genera.

After alignment the $r b c L$ sequences were trimmed to 1389 sites. Two sequences for Halophytum ameghinoi were combined to produce a usable length of 1187 sites. The matK alignments followed Cuenod et al. (2002). Ten informative presence/absence characters from $r b c L$ sequences and five from mat $K$ sequences were created for indels. The missing nucleotides were treated as missing values (Simmons and Ochoterena, 2000). 


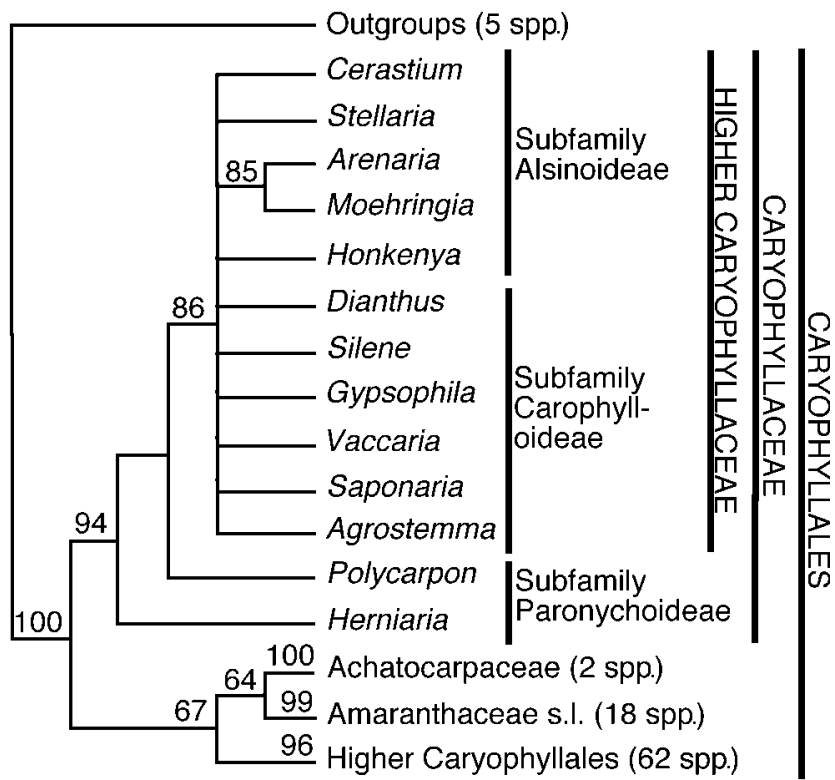

Fig. 1. A strict consensus of 513 parsimonious trees of 3647 steps (excluding uninformative characters, with a consistency index of 0.383) from analysis of 80 extant species based on 810 informative characters. Bootstrap percentages are shown above branches. Some well-supported branches have been collapsed, even though significant structure occurred within these clades. For each of these groups the number of species analyzed is indicated.

Most morphological/anatomical characters (Table 1) were derived from Rodman's (1994) characters, but were scored following an exemplar approach (Prendini, 2001) rather than inferring basal states for families. Preference was given to characters that could be scored unambiguously on the fossil. The data included 23 characters. Twenty morphological characters were compiled from Ross-Craig (1951), Roles (1957), Davis (1967), Dyer (1975), Nowicke and Skvarla (1979), Manly and Hutchins (1980), Cronquist (1981), Correa (1984), Eliasson (1993), Kubitzki et al. (1993), Nowicke (1994, 1996), Hofmann (1994), and Punt and Höen (1995). Of these, 19 could be scored on the fossil. One character was biochemical (pigment type; scored from Clements et al. [1994] and Cuenod et al. [2002]). Two characters described sieve element plastids (Behnke, 1994).

Cladistic analyses-PAUP version 4.0 (Swofford, 2000) was used to seek most-parsimonious trees. All characters were analyzed both for extant species only and for extant species and the fossil (Appendix 2, archived at the Botanical Society of America website [http://ajbsupp.botany.org/V90/]). These analyses used random addition sequences replicated 100 times, with tree bisection-reconnection, saving multiple trees. Branch support for the analysis of extant species was assessed by bootstrap with 1000 replicate heuristic searches, each using simple addition sequence, saving a single tree at each step and, because of memory limitations, restricting each replicate to $10^{8}$ rearrangements.

The power of phylogenetic placements using the limited data available on the fossil was tested following Jordan and Hill (2000). For each extant species, a matrix (Appendix 3, archived at the Botanical Society of America website [http://ajbsupp.botany.org/V90/]) was created. The relevant species was coded only for characters that could be scored on the fossil (thus simulating a fossil). All characters were coded for the other 79 extant species. The most-parsimonious phylogenetic placement of each extant species using this restricted data was then compared with its placement based on the complete data.

\section{RESULTS}

The analysis of extant species alone (Fig. 1), produced a moderately well-resolved consensus. Four major clades were

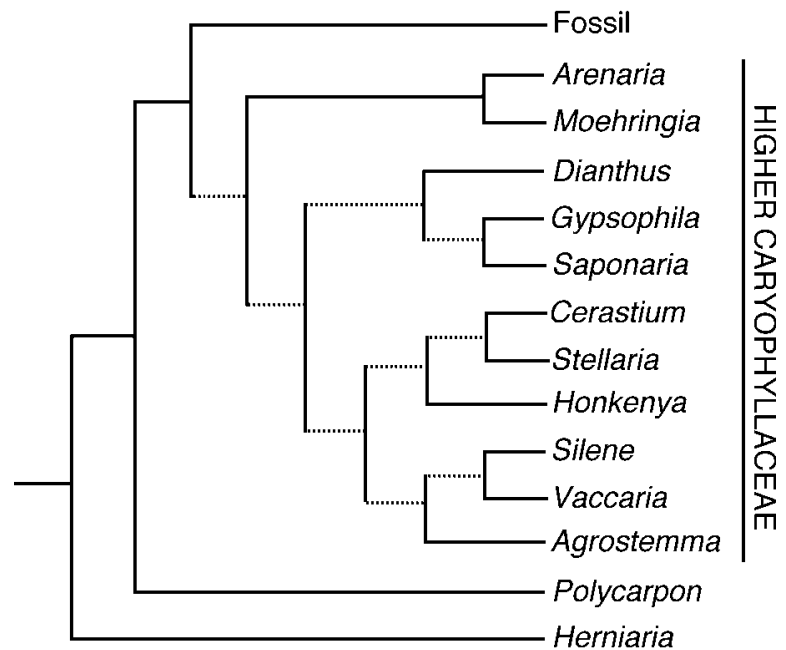

Fig. 2. Part of one of 6609 equally parsimonious trees from analysis of the fossil and 80 extant species. Branches with dashed lines collapsed in the strict consensus. The remainder of the consensus tree had the same topology as in Fig. 1. The trees were 3648 steps long (excluding uninformative characters), with a consistency index of 0.383 .

well supported: (1) Caryophyllales sensu stricto; (2) higher Caryophyllales, i.e., Phytolaccaceae, Agdestidaceae, Rivinaceae, Nyctaginaceae, Cactaceae, Aizoaceae, Didiereaceae, Bassellaceae, Portulacaceae, Stegnospermataceae, Halophytaceae, Barbeuiaceae, and Molluginaceae; (3) Caryophyllaceae; and (4) the higher Caryophyllaceae, i.e., subfamilies Caryophylloideae and Alsinoideae.

The fossil was most parsimoniously placed in a polytomy within, or as sister to, the higher Caryophyllaceae (Fig. 2). Trees only two steps longer than the most-parsimonious trees placed the fossil outside higher Caryophyllaceae, suggesting that support for the placement of the fossil within higher Caryophyllaceae was not strong (Källersjö et al., 1992). The placement within Caryophyllaceae is better supported: the shortest trees placing the fossil outside the family were three steps longer. These placed the fossil in a number of basal positions with the Caryophyllales.

The power to identify fossils-The analyses of extant species in which data for one species was restricted to characters that could be measured on fossils are too complex to present here in detail. The following is a summary. For each of the 11 extant species of the higher Caryophyllaceae in the data used here, the strict consensus tree unambiguously placed the relevant species with the other species of that clade. None of the 67 nonmembers of this clade was placed within it. Both sampled members of Caryophyllaceae subfamily Paronychoideae were placed within a clade containing the other members of Caryophyllaceae. No nonmember of Caryophyllaceae was placed within the Caryophyllaceae clade. These data imply that, given only the characters measured on the fossil, species of Caryophyllaceae would be correctly identified as members of that family, and similarly, species of higher Caryophyllaceae would be correctly placed within that clade. Furthermore, the data suggests that placement of any nonmember of Caryophyllaceae as a member of that family is unlikely. 


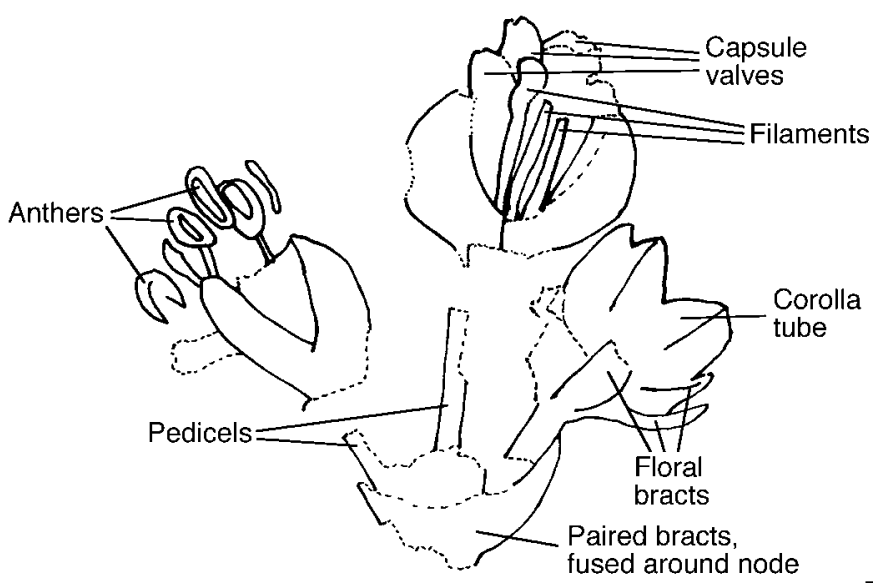

Fig. 3. Line drawing of holotype of Caryophylloflora paleogenica G. J. Jord. \& Macphail, sp. nov. (LA218). See also Figs. 4-7.

\section{SYSTEMATIC DESCRIPTION}

Class-Magnoliopsida.

Order-Caryophyllales.

Family—Caryophyllaceae.

Genus-Caryophylloflora G. J. Jord. \& Macphail genus nov.

Etymology - In reference to the association with Caryophyllaceae.

Diagnosis-Inflorescence dichasial, bracts fused around each node. Flowers with several bracts appressed to the calyx. Calyx a five-lobed tube. Stamens free, five opposite and five alternate to the sepals. Ovary syncarpous, superior. Pollen a sphaeroidal, periporate monad with nonannulate, circular pores; exine perforate, tectate with clearly visible columellae.

Species-Caryophylloflora paleogenica G. J. Jord. \& Macphail sp. nov. (Figs. 3-22).

Holotype-Specimen LA218, stored in the School of Plant Science, University of Tasmania.

Locality - Locharbour mine, northeastern Tasmania, Australia $40^{\circ} 56^{\prime} 16^{\prime \prime} \mathrm{S}, 148^{\circ} 0^{\prime} 34^{\prime \prime} \mathrm{E}$.

Age-Middle to Late Eocene.

Etymology - In reference to the Paleogene age of the fossil.

Diagnosis-Inflorescence an open dichasium with at least three flowers. Flowers hermaphrodite or unisexual. Pedicels 5-10 mm long, subtended by acute bracts, pairs of bracts fused around the peduncle. Floral bracts acute, imbricate, about as long as the calyx tube. Calyx tube approximately $3 \mathrm{~mm}$ long, lobes triangular, obtuse, approximately two-thirds as long as the tube. Stamens slightly exserted, filaments tapering slightly towards the apex. Anthers approximately $1 \mathrm{~mm}$ long, dorsifixed, tetrasporangiate, opening latrorsely by longitudinal slits.
Ovary opening by five valves. Pollen $24-(30)-32 \mu \mathrm{m}$ in diameter; amb circular; pores approximately $16,3-3.5 \mu \mathrm{m}$ in diameter, with or without a pore membrane; exine $2-2.5 \mu \mathrm{m}$ thick, sexine approximately $1.5 \mu \mathrm{m}$ thick, microreticulate-microechinate, thinner around pores, nexine $\ll 1 \mu \mathrm{m}$ thick, protruding through or invaginated within pores.

\section{DISCUSSION}

Phylogeny of extant species-The most parsimonious phylogeny was broadly consistent with those of Cuenod et al. (2002). The four major clades, Caryophyllales, higher Caryophyllales, Caryophyllaceae, and higher Caryophyllaceae (Fig. 1), were also strongly supported by earlier analyses (Downie and Palmer, 1994; Manhart and Rettig, 1994; Savolainen et al., 2000; Cuenod et al., 2002; Smissen et al., 2002).

In the most parsimonious trees (Fig. 1), all morphological characters are homoplasious, including some traditionally considered to be of taxonomic significance. Pollen ornamentation, aperture number and shape, stamen number and arrangement, perianth merosity and fusion all appear to have converged or reverted in several clades. For example, tricolpate and periporate pollen occur in both Caryophyllaceae and higher Caryophyllales. The strong support for these clades implies convergence in aperture shape and number.

Phylogenetic placement of the fossil-The analyses of the power to correctly classify fossils suggest that, given the characters available on the fossil, the approach used here would place only members of higher Caryophyllaceae within that clade. Combined with the additional numbers of steps required to place the fossil outside the clade, this makes the placement of C. paleogenica as a member of higher Caryophyllaceae (Fig. 2) convincing, in spite of extensive homoplasy. These interpretations assume that the fossil is a member of the order. However, the combination of periporate pollen, cymose inflorescence, fused calyx, and pentamerous flowers, with five stamens opposite the sepals and five alternate, makes placement in other groups unlikely.

The pollen grains of $C$. paleogenica (Figs. 9-22) are consistent with dispersed grains of Periporopollenites polyoratus from Australia and East Antarctica (Figs. 23-33). The dispersed grains are larger ( $39 \mu \mathrm{m}$ vs. $30 \mu \mathrm{m})$, but this is probably due to oxidization from weathering and palynological preparation. The grains of $C$. paleogenica differ from other Periporopollenites species described in Australia. They have larger and more pores than $P$. demarcatus Stover \& Partridge 1973 (Figs. 34-41) and P. hexaporus Macphail \& Hill 1994 (Figs. 43-45). They are smaller than P. vesicus Stover \& Partridge 1973, which does not have distinctly defined columellae. Periporopollenites pallidus Truswell \& Owen 1988 has more pores (20-30) and a thinner exine $(1-1.3 \mu \mathrm{m})$ that does not decrease in thickness around the pores.

The grains of $C$. paleogenica differ from all published extant Caryophyllaceae pollen (Heusser, 1971; Nowicke and Skvarla, 1979; Moar, 1993; Nowicke, 1994, 1996; Punt and Höen, 1995). Most extant Caryophyllaceae (e.g., Figs. 46-53) have (1) spinulose, not echinate pollen, (2) conspicuous spinulose opercula over the apertures, and (3) conspicuous perforations (Nowicke, 1994; Punt and Höen, 1995). Many have much larger perforations through the sexine (Nowicke, 1994; Punt and Höen, 1995). Some species, such as Melandrium apricum and Silene aperta, are finely reticulate (Nowicke, 


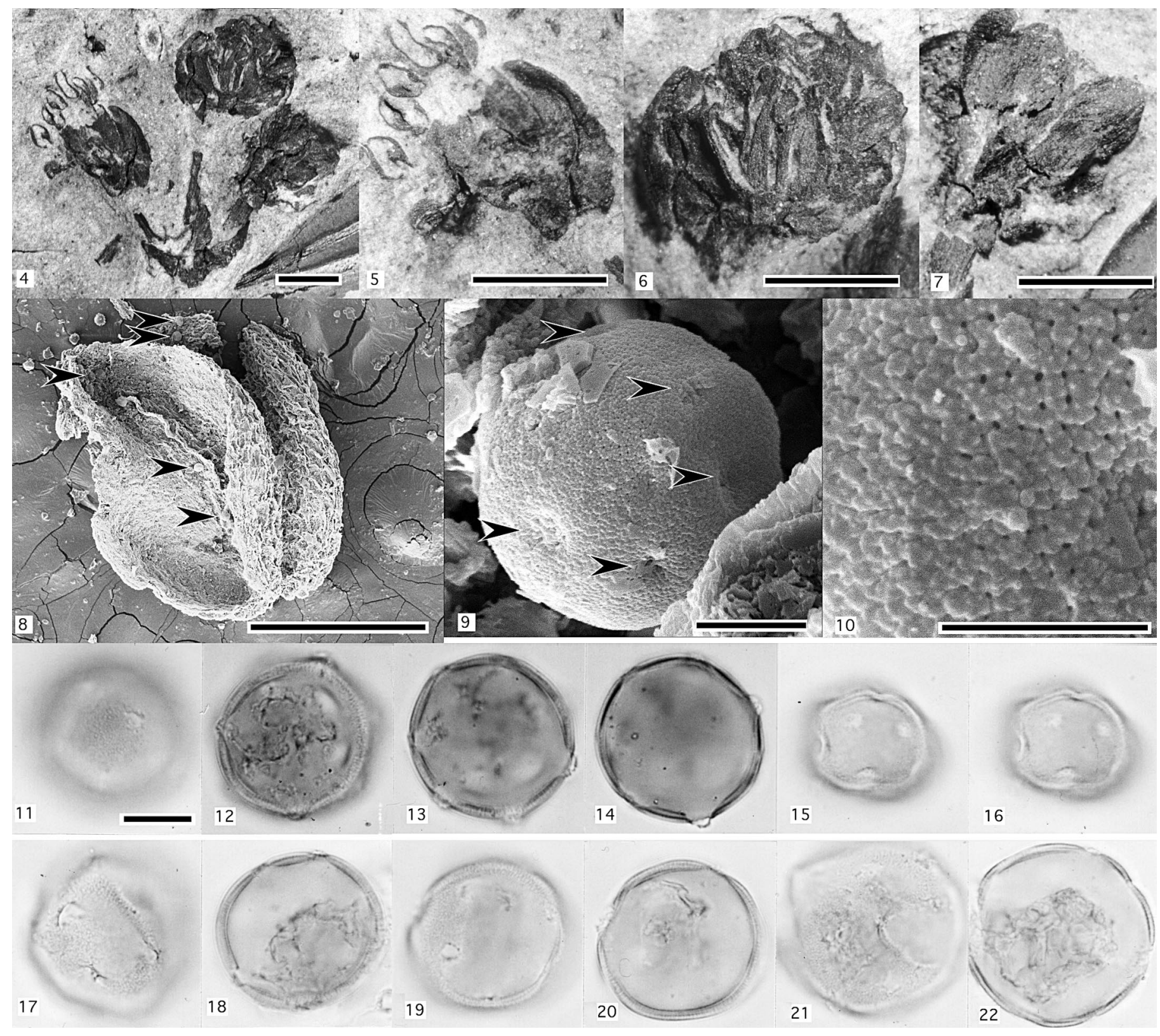

Figs. 4-22. Holotype of Caryophylloflora paleogenica G. J. Jord. \& Macphail, sp. nov. (LA218). 4. Fossil inflorescence (compare with Fig. 3). 5. Lefthand flower (staminate). 6. Middle flower (hermaphrodite). 7. Right-hand flower (pistillate). 8. Scanning electron micrograph of an anther. Note the two chambers and in situ pollen grains (indicated by arrows). 9. Scanning electron micrograph of an in situ pollen grain. Arrows indicate pores. 10. Detail of the grain illustrated in Fig. 9. Note the perforations and spinules. 11-22. Optical sections through unoxidized pollen grains from a crushed anther. Fig. 4, scale bar $=2$ mm; Figs. 5-7, scale bar $=1 \mathrm{~mm}$; Fig. 8, scale bar $=500 \mu \mathrm{m}$; Figs. 9, 11-22, scale bar $=10 \mu \mathrm{m}$; Fig. 10, scale bar $=5 \mu \mathrm{m}$.

1994; Punt and Höen, 1995), but this is due to large perforations unlike the fine ones of the fossil (Fig. 10). Illecebrum verticillatum, like the fossil, has echinate grains with fine perforations and little elaboration of the exine over the apertures, but has only 6-9 pores (Punt and Höen, 1995). The pollen is also distinct from other periporate Caryophyllales (e.g., Figs. 54-57). In particular, Amaranthaceae (including Chenopodiaceae) have annulate pores.

Caryophylloflora paleogenica is clearly distinct in floral form from any of the eight genera and 40 or so species of Caryophyllaceae native to Australia (Hnatiuk, 1990). Gypsophila lacks bracts appressed to the calyx. Arenaria, Stellaria,
Spergularia, Colobanthus, Polycarpea, and Drymaria have free sepals. In Scleranthus the stamens arise from the top of a hypanthium. Caryophylloflora paleogenica is therefore best considered as a member of an extinct genus. To establish the relationships of C. paleogenica within Caryophyllaceae more precisely would require a detailed phylogeny. This may be indecisive considering the morphological convergence in the order and lack of resolution among extant species (Fig. 1; Smissen et al., 2002).

Evolutionary and biogeographic implications-Caryophylloflora paleogenica implies that Caryophyllaceae were in Aus- 

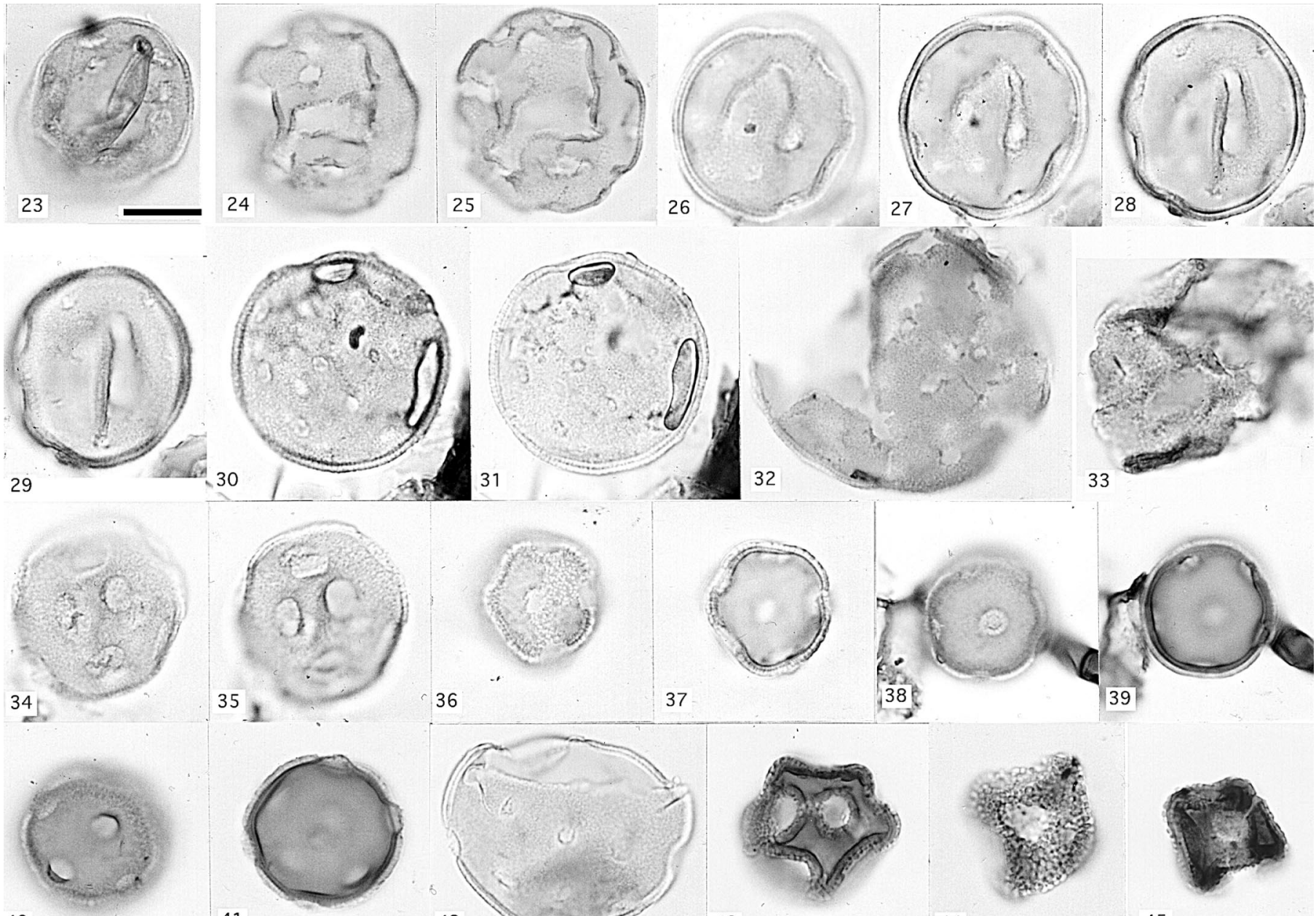

40

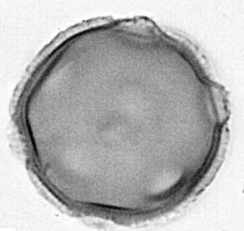

36

37
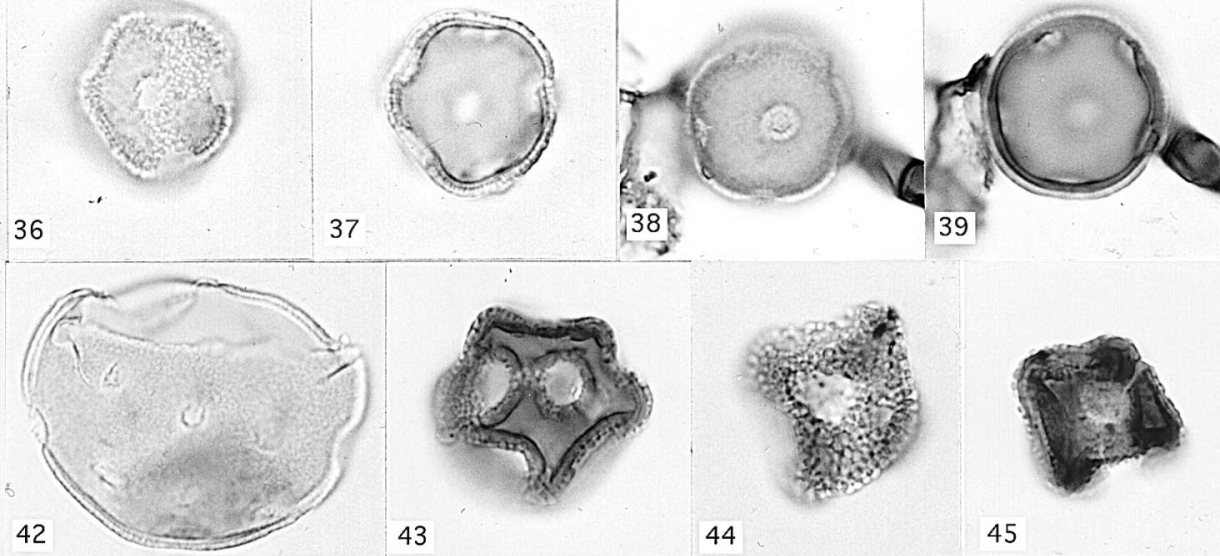

41

43

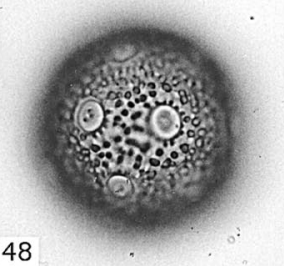

49
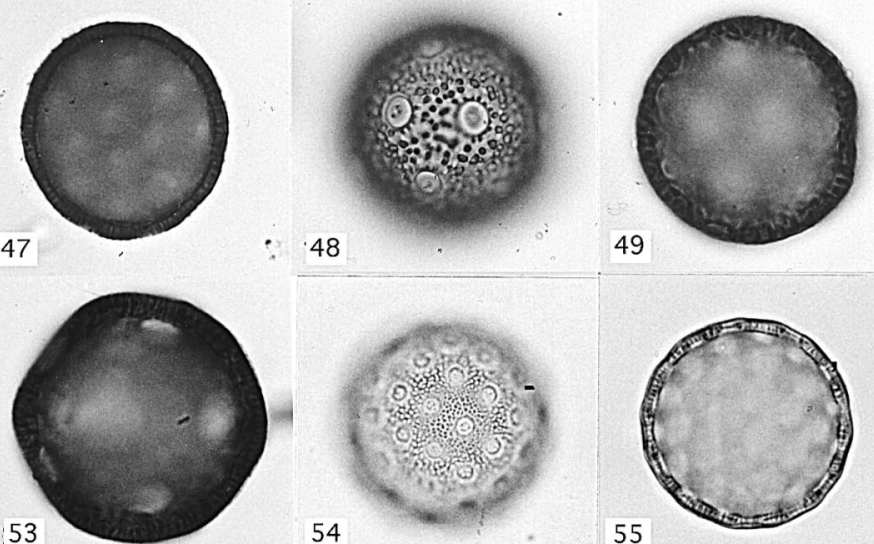

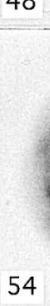

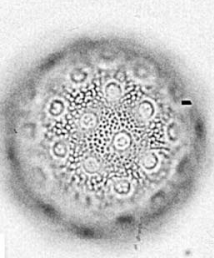

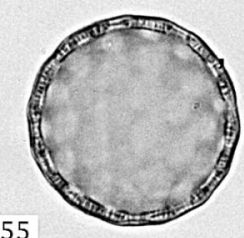

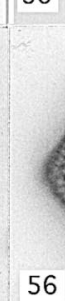

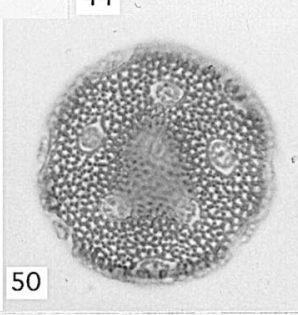

45
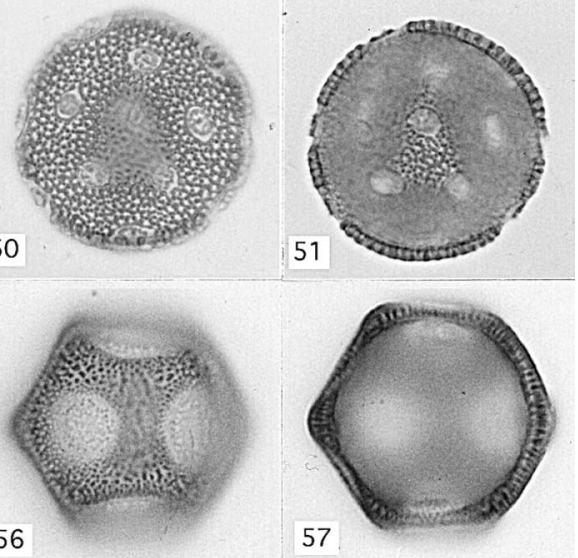

Figs. 23-57. Light micrographs of pollen grains of fossil Periporopollenites species (Figs. 23-45) and extant species of Caryophyllales (Figs. 46-57). Multiple images of specimens represent optical sections. 23-25. Periporopollenites polyoratus from latest Middle-Late Eocene glacio-marine sediments, 148.36 m, ODP Leg 188, Site 1166, Prydz Bay, East Antarctica. 26-31. Periporopollenites polyoratus from a Middle-Late Eocene backswamp deposit, Tallong, Southern Highlands, New South Wales, Australia. 32. Fragmented grain of Periporopollenites sp. cf. P. polyoratus from an Early Oligocene tillite, $39.93 \mathrm{~m}$ in Lemonthyme Creek DDH 5825, Northwest Tasmania, Australia. 33. Poorly preserved grain of $P$. polyoratus from Late Paleocene fluvio-deltaic sediments, 1923 m, Esso-BHP Snapper-1 Well, Gippsland Basin, southeast Australia. 34-37. Periporopollenites demarcatus from the Middle-Late Eocene Tallong sediments. 38-41. Periporopollenites demarcatus from Middle Eocene backswamp sediment, Nelly Creek, Lake Eyre Basin, Central Australia. 42. Fragmented grain of Periporopollenites sp. cf. P. polyoratus from the Middle-Late Eocene Tallong sediments. 43. Periporopollenites hexaporus from an Early Oligocene tillite, 21.34 m, Wilmot Dam DDH 4558, Northwest Tasmania. 44-45. Periporopollenites hexaporus from latest Middle-Late Eocene marginal marine sediments, 156.99 m, ODP Leg 188, Site 1166, Prydz Bay, East Antarctica. 46-47. Colobanthus apetalus (Caryophyllaceae). 48-49. Lychnis coronata (Caryophyllaceae). 50-51. Scleranthus diander (Caryophyllaceae). 52-53. Stellaria flaccida (Caryophyllaceae). 54-55. Suaeda australis (Amaranthaceae). 56-57. Hemichroa pentandra (Amaranthaceae). Scale bars $=10 \mu \mathrm{m}$. The larger bar applies to Figs. 23-45, the smaller to Figs. 46-57. 
tralia by the Late Eocene. It also confirms that at least some fossil pollen assigned to Periporopollenites polyoratus was produced by Caryophyllaceae. The placement of the fossil among or as sister to the higher Caryophyllaceae suggests that considerable divergence had occurred within the family by the Late Eocene. Furthermore, the distinct nature of $C$. paleogenica and the absence of $P$. polyoratus after the Oligocene implies that Paleogene Caryophyllaceae in Australia may not have been closely related to extant Australian members of the family.

Most extant Australian genera of Caryophyllaceae are best interpreted as having arrived during the Neogene or Quaternary. Arenaria, Gypsophila, Stellaria, and Spergularia are cosmopolitan or primarily Eurasian, and the Australian species are identical to or closely related to temperate Eurasian species. Fossil pollen closely resembling that produced by Stellaria (Polyporina granulatus Martin 1973) and Silene (Polyporina reticulata Martin 1973) first appear in southern Australia during the Late Miocene-Early Pliocene (Macphail, 1997). This suggests relatively recent dispersal. Polycarpea and the Australian species of Drymaria, D. cordata, are more or less pantropical (Bittrich, 1993). Transoceanic dispersal appears to have been significant in both Colobanthus and Scleranthus. The former occurs on isolated islands of relatively recent origin (e.g., Macquarie Island), and species of the latter (S. biflorus and $S$. brockei) occur in both Tasmania and New Zealand, a distribution unlikely to have arisen through vicariance (see Jordan, 2001). Thus, although C. paleogenica demonstrates that the family grew in the Southern Hemisphere by the Middle-Late Eocene, modern Australian Caryophyllaceae appear to be independent, recent arrivals.

\section{LITERATURE CITED}

BAillie, P. W. 1989. Jurassic-Cainozoic. In C. F. Burrett and E. L. Martin [eds.], Geology and mineral resources of Tasmania, 339-409. Geological Society of Australia, Melbourne, Australia.

BARnES, R. W., AND G. J. JoRdAN. 2000. Eucryphia (Cunoniaceae) reproductive and leaf macrofossils from Australian Cainozoic sediments. Aus tralian Systematic Botany 13: 373-394.

BennKe, H.-D. 1994. Sieve-element plastids: their significance for the evolution and systematics of the order. In H.-D. Behnke and J. T. Mabry [eds.], Caryophyllales: evolution and systematics, 87-122. Springer Verlag, Berlin, Germany.

BitTrich, V. 1993. Caryophyllaceae. In K. Kubitzki, J. G. Rohwer, and V. Bittrich [eds.], The families and genera of vascular plants, vol. II, Flowering plants, dicotyledons, Magnoliid, Hamamelid and Caryophyllid Families, 206-236. Springer-Verlag, Berlin, Germany.

Carpenter, R. J., R. S. Hill, and G. J. Jordan. 1994. Cenozoic vegetation in Tasmania. In R. S. Hill [ed.], History of the Australian vegetation: Cretaceous to Recent, 276-298. Cambridge University Press, Cambridge, UK.

Chandler, E. M. 1961. Flora of the Lower Headon Beds of Hampshire and the Isle of Wight. Bulletin of the British Museum of Natural History: Geology 5: 91-158.

Chandler, E. M. 1963. The lower Tertiary floras of South England. III. Flora of the Bournemouth Beds; the Boscombe, and the Highcliff Sands. The British Museum, London, UK.

Clements, J. S., J. T. Mabry, H. Wyler, And A. S. Drieding. 1994. Chemical review and evolutionary significance of betalaines. In H.-D. Behnke and J. T. Mabry, [eds.], Caryophyllales: evolution and systematics, 247262. Springer Verlag, Berlin, Germany.

Correa, M. N. 1984. Flora Patagonica. Instituto Nacional de Tecnologia Agropecuaria, Buenos Aires, Argentina.

CRONQUist, A. 1981. An integrated system of classification of flowering plants. Columbia University Press, New York, New York, USA.

Cuenod, P., V. Savolainen, L. W. Chatrou, M. Powell, R. E. J. Grayer, AND M. W. Chase. 2002. Molecular phylogenetics of Caryophyllales based on nuclear 18s rDNA and plastid $r b c L$, atpB, and matK DNA sequences. American Journal of Botany 89: 132-144.

DAvis, P. H. 1967. Flora of Turkey and the East Aegean Islands, vol. 2. Edinburgh University Press, Edinburgh, UK.

Dilcher, D. L. 2000. Toward a new synthesis: major evolutionary trends in the angiosperm fossil record. Proceedings of the Natonal Academy of Sciences 97: 7030-7036.

DownIE, S. R., AND D. PALMER. 1994. A chloroplast DNA phylogeny of the Caryophyllales based on structural and inverted repeat restriction site analysis. Systematic Botany 19: 236-252.

DYER, R. A. 1975. The genera of southern African flowering plants, vol. 1, Dicotyledons. Department of Agriculture Technical Services, Pretoria, South Africa.

Eliasson, U. 1993. 35A, Phytolaccaceae, Flora of Ecuador, 46. University of Goteborg Press, Goteborg, Sweden.

Heusser, C. J. 1971. Pollen and spores of Chile. Modern types of the Pteridophyta, Gymnospermae, and Angiospermae. University of Arizona Press, Tucson, Arizona, USA.

HiLl, R. S. 1989. New species of Phyllocladus (Podocarpaceae) macrofossils from south eastern Australia. Alcheringa 13: 193-208.

Hill, R. S., AND R. J. CARPENTER. 1991. Evolution of Acmopyle and Dacrycarpus (Podocarpaceae) foliage as inferred from macrofossils in southeastern Australia. Australian Systematic Botany 4: 449-479.

Hill, R. S., AND D. C. Christophel. 1988. Tertiary leaves of the tribe Banksieae (Proteaceae) from southeastern Australia. Botanical Journal of the Linnean Society 97: 205-227.

Hill, R. S., AND M. S. Pole. 1992. Leaf and shoot morphology of extant Afrocarpus, Nageia and Retrophyllum (Podocarpaceae) species, and species with similar leaf arrangement from Tertiary sediments in Australasia. Australian Systematic Botany 5: 337-358.

HNAtiuk, R. J. 1990. Census of Australian vascular plants. Australian Government Publishing Service, Canberra, Australia.

HofmanN, U. 1994. Flower morphology and ontogeny. In H.-D. Behnke and J. T. Mabry [eds.], Caryophyllales: evolution and systematics, 123-166. Springer Verlag, Berlin, Germany.

JorDAN, G. J. 2001. An investigation of long-distance dispersal based on species native to both Tasmania and New Zealand. Australian Journal of Botany 49: 333-340.

Jordan, G. J., AND R. S. Hill. 2000. The phylogenetic affinities of Nothofagus leaf fossils based on combined molecular and morphological data. International Journal of Plant Science 160: 1177-1188.

Källersjö, M., J. S. Farris, A. G. Kluge, And C. Bult. 1992. Skewness and permutation. Cladistics 8: 275-287.

Kubitzki, K., J. G. Rohwer, And V. BitTrich. 1993. The families and genera of vascular plants, vol. II, Flowering plants, dicotyledons, Magnoliid, Hamamelid and Caryophyllid Families. Springer-Verlag, Berlin, Germany.

MacPhaIL, M. K. 1997. Late Neogene climates in Australia: fossil pollenand spore-based estimates in retrospect and prospect. Australian Journal of Botany 45: 425-464.

Macphail, M. K., N. Alley, E. M. Truswell, and I. R. Sluiter. 1994. Early Tertiary vegetation: evidence from pollen and spores. In R. S. Hil [ed.], History of the Australian vegetation: Cretaceous to Recent, 189261. Cambridge University Press, Cambridge, UK.

Manhart, J. R., And J. H. Rettig. 1994. Gene sequence data. In H.-D. Behnke and J. T. Mabry [eds.], Caryophyllales: evolution and systematics, 235-246. Springer Verlag, Berlin, Germany.

Manly, W. C., And C. R. Hutchins. 1980. A flora of New Mexico. J. Cramer, Vaduz, Germany.

MoAr, N. T. 1993. Pollen grains of New Zealand dicotyledonous plants. Manaaki Whenua Press, Lincoln, New Zealand.

Muller, J. 1981. Fossil pollen records of extant angiosperms. Botanical Review 47: 1-142.

Nott, J. F., AND J. A. K. Owen. 1992. An Oligocene palynoflora from the middle Shoalhaven catchment N.S.W. and the Tertiary evolution of flora and climate in the southeast Australian highlands. Palaeogeography, $\mathrm{Pa}$ laeoclimatology, Palaeoecology 95: 135-151.

NowICKE, J. W. 1994. Pollen morphology and exine ultrastructure. In H.-D. Behnke and J. T. Mabry [eds.], Caryophyllales: evolution and systematics, 168-221. Springer Verlag, Berlin, Germany.

Nowicke, J. W. 1996. Pollen morphology, exine structure and the relationships of Basellaceae and Didieraceae to Portulacaceae. Systematic Botany 21: $187-208$ 
Nowicke, J. W., AND J. J. SKVARLA. 1979. Pollen morphology: the potential influence in higher order systematics. Annals of the Missouri Botanic Gardens 66: 633-700.

OwEn, J. A. K. 1988. Miocene palynomorph assemblages from Kiandra, New South Wales. Alcheringa 12: 269-297.

PRENDINI, L. 2001. Species or supraspecific taxa as terminals in cladistic analysis? Groundplans versus exemplars revisited. Systematic Biology 50: 290-300.

Punt, W., AND P. P. HöEn. 1995. Caryophyllaceae. Review of Palaeobotany and Palynology 88: 82-272.

RAINE, J. I. 1984. Outline of a palynological zonation of Cretaceous to Paleogene terrestrial sediments in West Coast region, South Island, New Zealand. New Zealand Geological Survey Report 109: 1-82.

Rodman, J. E. 1994. Cladistic and phenetic studies. In H.-D. Behnke and J. T. Mabry [eds.], Caryophyllales: evolution and systematics, 279-301. Springer Verlag, Berlin, Germany.

Roles, S. J. 1957. Flora of the British Isles, illustrations, part 1. Cambridge University Press, Cambridge, UK.

Ross-Craig, S. 1951. Drawings of the British Flora, vol. 5, Caryophyllaceae. G. Bell and Sons, London, Great Britain.
Savolainen, V., ET AL. 2000. Phylogeny of the eudicots: a nearly complete familial analysis based on $r b c L$ gene sequences. Kew Bulletin 555: $257-$ 309.

Simmons, M. P., AND H. OCHOTERENA. 2000. Gaps as characters in sequencebased phylogenetic analyses. Systematic Biology 49: 369-381.

Smissen, R. D., J. C. Clement, P. J. Garnock-Jones, and G. K. Chambers. 2002. Subfamilial relationships within Caryophyllaceae as inferred from 5' ndhF sequences. American Journal of Botany 89: 1336-1341.

Stover, L. E., And A. D. Partridge. 1973. Tertiary and Late Cretaceous spores and pollen from the Gippsland Basin, south-eastern Australia. Proceedings of the Royal Society of Victoria 85: 237-286.

SWOFFORD, D. L. 2000. PAUP*: phylogenetic analysis using parsimony (*and other methods), version 4. Sinauer, Sunderland, Massachusetts, USA.

Truswell, E. M., I. R. Sluiter, And W. K. Harris. 1985. Palynology of the Oligocene-Miocene sequence in the Oakvale-1 corehole, western Murray Basin, South Australia. BMR Journal of Australian Geology and Geophysics 9: 267-295.

Tulip, J. R., G. TAYlor, And E. M. Truswell. 1982. Palynology of Tertiary Lake Bunyan, Cooma, New South Wales. BMR Journal of Australian Geology \& Geophysics 7: 255-268. 